\title{
$\mathrm{CaO} / \mathrm{SiO}_{2}$ 비 및 W/B 변화에 따른 오토클레이브 양생 경화체의 특성에 관한 실험적 연구
}

\author{
강철 ${ }^{1)} \cdot$ 강기웅 ${ }^{2} \cdot$ 김진만 ${ }^{1) \star}$ \\ ${ }^{1)}$ 공주대학교 건축학부 ${ }^{2)}$ 대한주택공사
}

\section{Experimental Study on the Properties of Solid Material Made by Autoclave Curing according to $\mathrm{CaO} / \mathrm{SiO}_{2}$ Ratio and $\mathrm{W} / \mathrm{B}$}

\author{
Cheol Kang, ${ }^{1)}$ Ki-Woong Kang, ${ }^{2)}$ and Jin-Man Kim ${ }^{1) *}$ \\ ${ }^{1)}$ Dept. of Architecture, Kongju National University, Cheonan 330-717, Korea \\ ${ }^{2)}$ Korea National Housing Corporation, Seongnam 463-704, Korea
}

\begin{abstract}
This study is on the properties of inorganic porous calcium silicate material made from silica powder through the autoclaving curing, the results of this study should be utilized fundamental data for the development of noise reduction porous solid material using siliceous byproduct generated by various manufacture process. For the manufacture of autoclave curing specimen, various calcareous materials used and siliceous materials used silica powder. In this study, properties in density and compressive strength according to the change of W/B and C/S ratio, microscopy for the shape of pore, SEM and XRD for the examination of hydrate after autoclave curing are carried out respectively. The test results shown that the more slurry density decrease, the more W/B increase at the fresh state, this tendency shown similar to in hardened state. Among the specimens of C/S ratio, the compressive strength of $\mathrm{C} / \mathrm{S}$ ratio of 0.85 gave the highest the compressive strength. In the results of $\mathrm{XRD}$, tobermorite generated by autoclaving curing was created all of specimens regardless of $\mathrm{C} / \mathrm{S}$ ratio. To ascertain pore structure, we compared with existing porous calcium silicate product(ALC, organic sound absorbing porous material). The results of microscope observation, pore structure of specimen of this study was similar to that of existing inorganic sound absorbing foam concrete. therefore, we could conformed a possibility of sound absorbing porous solid material on the basis of the results.
\end{abstract}

Keywords : autoclave, hydro-thermal synthetic reaction, C/S ratio, tobermorite, pore

\section{1. 서 론}

건축구조물의 대형화, 고층화 추세에 따라 자중 경감 등의 구조적 문제 해결을 위해 비내력 벽체 및 커튼월 등에 경량의 프리캐스트 제품 등의 사용이 증가하고 있 다. 이 중 경량기포콘크리트는 건축의 공장생산화 실현, 건물의 질적 향상, 현장시공의 단순화에 따르는 건설공 사 비용의 절감 및 작업환경 등에 기여할 수 있는 것으 로 알려져 왔다. ${ }^{1)}$

경량기포콘크리트 중 생석회 $(\mathrm{CaO})$ 와 실리카 $\left(\mathrm{SiO}_{2}\right)$ 또 는 포틀랜드시멘트를 주원료로 오토클레이브를 사용하여 $170 \sim 250^{\circ} \mathrm{C}$ 의 포화수증기압 하에서 처리하여 얻을 수 있 는 재료를 오토클레이브 처리 규산칼슘재료(autoclaved calcium silicate product)라고 한다. ${ }^{2-6)}$ 그 중 $\mathrm{ALC}$ 는 방화,

*Corresponding author E-mail : jmkim@kongju.ac.kr Received December 30, 2008, Revised May 27, 2009 Accepted July 15, 2009

(c) 2009 by Korea Concrete Institute
내화, 단열, 차음 등의 성능이 우수하여 내부칸막이벽체 로 많이 사용하고 있다. $\mathrm{ALC}$ 는 규사, 규석분말 등의 미 세분말과 석회와 물을 혼합한 슬러리에 인공적으로 내부 에 기포를 발생시켜 다공질화 한 것으로 기공형성을 위 해 사용되는 알루미나 파우더나 페이스트가 시멘트 및 석회와의 화학반응에 의한 수소가스 발생으로 내부에 닫 힌 기공을 형성시킴으로써 단열성능 및 차음성능을 유지 하게 된다.

하지만 $\mathrm{ALC}$ 는 장점도 많지만, 제조되는 제품의 품위가 한정되어 있어 사용되는 장소 및 부위선정에 제약이 있고, 규사분 및 규석분 등의 고품질의 천연재료를 사용해서 제 조되기 때문에, 자원고갈로 인한 가격상승 및 환경보존의 강화로 인한 원료의 생산에 대한 규제가 심해지고 있다.

한편, 생활수준의 향상과 쾌적한 거주공간에 대한 의 식욕구가 높아지면서, 그 중 소음방지계획은 쾌적한 거 주공간 창출 및 프라이버시 확보를 위해서도 당연히 고 려해야 하는 성능항목이 되고 있다. 더구나 건축공간의 고밀화나 생활패턴의 변화, 교통기관이나 생산시설의 발 
전에 따른 소음발생원의 증가와 발생소음레벨의 증대 등 최근 추세는 건축물에 있어서 소음방지설계의 중요성을 재인식시키고 있다. 소음저감 및 방지에 사용되는 재료 는 크게 흡음재료와 차음재료로 구분될 수 있다. 이 중 흡음재료는 공기 중을 전파하여 입사한 음파가 반사되는 양이 적은 재료로 주로 천장, 벽, 내장재료 및 도로의 방 음벽 등에 사용된다. 사용되는 재료로는 크게 다공질 흡 음재료, 다공질판 흡음재료 및 구멍판 흡음재료로 나뉜다.

흡음재의 경우 섬유상의 유리솜(glass wool)과 암면(rock wool $)^{8)}$ 이 많이 사용되고 있으며, 이들 재료는 내부에 많 은 공기층을 포함하고 있는 다공질재료다. 하지만 이들 재료는 시간 경과에 따른 성능감소와 재료특성에 따른 문제점이 발생하고 있어 이를 대체할 수 있는 새로운 재 료의 개발이 요구되고 있다. 그래서 이러한 목적에 부합 하기 위해 경량기포콘크리트를 흡음재로 적용하기 위한 연구가 진행된 적이 있으나 현재 실용화 및 후속 진행 에 대한 연구는 크게 이루어지지 않고 있는 실정이다.

따라서 이 연구에서는 음향재료로 사용할 수 있는 다 공성 경화체를 개발하기 위한 일련의 연구로서 먼저 오 토클레이브양생 경화체 제조에 사용되는 대표적인 재료 인 규사분을 이용하여 $\mathrm{CaO} / \mathrm{SiO}_{2}$ 비(이하 $\mathrm{C} / \mathrm{S}$ 비로 함) 및 물분체비(이하 W/B로 함) 변화에 따른 특성을 검토하여, 소음 저감형 다공성 경화체 개발에 관한 연구의 기초적 자료로 활용하고자 하였다.

\section{2. 실험 계획 및 방법}

\section{1실험 계획}

이 연구에서는 사용재료의 $\mathrm{C} / \mathrm{S}$ 비 및 $\mathrm{W} / \mathrm{B}$ 변화에 따른 오토클레이브 경화체의 특성을 알아보기 위하여 실험을 Table 1 과 같이 계획하여 실시하였으며 기포율 및 공극 특성에 관한 상세한 검토는 이 논문의 범위에 포함시키 지 않고 이 연구 결과를 바탕으로 후속 연구에서 진행 하는 것으로 하였다. 실험계획은 기존문헌 ${ }^{9-10)}$ 을 참고하 여 오토클레이브 수화물인 토버모라이트(tobermorite) 형 성을 위한 $\mathrm{C} / \mathrm{S}$ 비를 0.85 를 중심으로 4 수준 $(0.75,0.8$, $0.85,0.9)$ 을, $\mathrm{W} / \mathrm{B}$ 는 규사분을 제외한 분체계 재료(시멘 트, 석고, 소석회, 알루미나시멘트)의 중량비율로 4수준 $(120,130,140,150)$ 으로 선정한 뒤 배합수 $(\mathrm{Mw})$ 는 $50 \%$ 로 고정시키고 기포수 $(\mathrm{Fw})$ 를 변화시켜 굳지 않은 상태 및 굳은 상태 그리고 오토클레이브양생 후의 강도특성 및 화학적 특성을 검토하였다. 또한 $\mathrm{C} / \mathrm{S}$ 비 및 $\mathrm{W} / \mathrm{B}$ 변화

Table 1 The design of experiment

\begin{tabular}{c|c|l}
\hline Experiment factor & Level & \multicolumn{1}{|c}{ Test item } \\
\hline \hline \multirow{2}{*}{ C/S ratio } & $0.75,0.80$ & Slurry density \\
& $0.85,0.90$ & Oven dry density \\
Compressive strength \\
W/B & 120,130 & XRD \\
& 140,150 & Microscope observation \\
\hline
\end{tabular}

에 따른 밀도 및 압축강도 특성에 미치는 주요한 영향 을 알아보기 위하여 실험계획법 중 이원배치법을 적용하 여 실험하였고, 그 결과를 분산분석 후 $\mathrm{F}$-검정을 실시하 여 영향성을 평가하였다.

\section{2 성능목표}

이 연구에서는 경량기포콘크리트의 용도를 흡음재로 선정하였다. 흡음재의 특성을 나타내는 요소 중의 하나 로 흡음률이 사용된다. 흡음률은 음향재료나 구조물에 입 사된 음향에너지 중에서 반사되거나 투과되지 않고 흡음 된 에너지의 비율로 정의된다. ${ }^{11}{ }^{11}$ 일반적으로 흡음률의 측 정 및 성능과 관련하여 많은 규격들이 있는데 그 중 대표 적인 것은 KS F 2805 「잔향실 내의 흡음률 측정 방법」, KS F 2814-2「임피던스관에 의한 흡음계수와 임피던스 결정방법-전달함수법」, 그리고 KS F ISO 11654 건축물 용 흡음재의 흡음성능 평가 방법이 있다. 이 연구에서는 이 중 KS F 2805 「잔향실 내의 흡음률 측정 방법」을 이용하여 기존에 사용되고 있는 유리면, 또는 암면의 흡 음성능을 나타낼 수 있는 흡음률 0.7 이상을 성능목표로 설정하였다.

\section{3 사용 재료}

규산질 원료는 $\mathrm{SiO}_{2}$ 성분으로 대표되는 것으로 시멘트 의 주성분인 $\mathrm{CaO}$ 성분과 고온 · 고압의 양생 하에서 토 버모라이트라는 수화물을 생성하게 된다. 이것은 오토클 레이브 경화체의 강도특성을 좌우한다. 이 연구에 사용 한 규산질 재료는 일반적으로 $\mathrm{ALC}$ 의 제조에 사용되는 규사분으로 밀도 $2.65\left(\mathrm{~kg} / \mathrm{m}^{3}\right)$, 분말도 $3,500\left(\mathrm{~cm}^{2} / \mathrm{g}\right)$ 인 충북 금평산 제품을 사용하였다. 시멘트는 밀도 $3.15\left(\mathrm{~kg} / \mathrm{m}^{3}\right)$ 인 S 사 보통포틀랜드시멘트를 사용하였고, 혼화재로서는 초 기 경화촉진을 위한 알루미나시멘트와 경화체의 안정성 확보를 위해 소석회, 그리고 응결시간 조절을 위한 무수 석고를 사용하였으며, 사용재료의 화학조성은 Table 2 와 같다. 오토클레이브 경화체의 밀도 조절 및 공극형성을 위해 사용한 기포제는 $\mathrm{A}$ 사의 알코올에톡시설포네이트 (alcohol ethoxy sulphonate)계면활성제를, 단위수량 저감 을 위한 감수제는 $\mathrm{K}$ 사의 나프탈렌계를 사용하였다.

Table 2 Chemical composition of the materials

\begin{tabular}{c|c|c|c|c|c|c|c|c|c}
\hline \multirow{2}{*}{ Sample } & \multicolumn{7}{|c}{ Chemical composition (\% by weight) } \\
\cline { 2 - 11 } & $\mathrm{SiO}_{2}$ & $\mathrm{Al}_{2} \mathrm{O}_{3}$ & $\mathrm{Fe}_{2} \mathrm{O}_{3}$ & $\mathrm{CaO}$ & $\mathrm{MgO}$ & $\mathrm{K}_{2} \mathrm{O}$ & $\mathrm{SO}_{3}$ & $\mathrm{TiO}_{2}$ & Ig.loss \\
\hline \hline $\mathrm{SP}$ & 90.0 & 4.1 & 1.6 & 0.6 & 0.1 & 0.8 & - & 1.5 & 1.3 \\
\hline $\mathrm{OPC}$ & 24.6 & 6.1 & 3.0 & 60.8 & 1.7 & 0.69 & 0.11 & 1.3 & 1.7 \\
\hline $\mathrm{AC}$ & 4.2 & 54.7 & 0.6 & 36.9 & - & 0.2 & 0.1 & 3 & 0.3 \\
\hline $\mathrm{CH}$ & - & - & - & 73.3 & - & - & - & - & 26.7 \\
\hline $\mathrm{A}$ & 3.7 & 0.7 & - & 38.3 & - & - & 54.4 & - & 2.9 \\
\hline $\mathrm{SP}$
\end{tabular}

SP : silica powder, OPC : ordinary portland cement

$\mathrm{AC}$ : alumina cement, $\mathrm{CH}$ : calcium hydroxide, A : anhydrite 


\section{4 실험 방법}

\subsection{1 제조}

이 연구에서 적용한 $\mathrm{W} / \mathrm{B}$ 는 분체계 재료를 슬러리화 하는데 필요한 배합수량과 기포발생을 위해 필요한 기포 수량으로 구분할 수 있다. 따라서 우선적으로 분체계 재 료를 슬러리 상태로 만들기 위해 배합수를 투입하고, 남 은 기포수는 발포장치를 통해 제조된 기포와 함께 슬러 리에 투입하여 슬러리와 기포가 균질하도록 혼합하였다. Fig. 1은 선발포 방식을 이용한 다공성 경화체의 제조방 법 프로세스를 나타낸 것이다.

\subsection{2양생}

경화체 제조를 위한 양생단계별 과정은 Fig. 2 와 같이 전치양생(precuring, A section), 증기양생(steam curing $\mathrm{B}$ section), 안정기(interval, C section), 오토클레이브양생(autoclave curing, D section) 후에 서냉기(cooling, E section)를 두는 것으로 하였다.

전치양생은 사용재료 중의 알루미나의 응결촉진작용에 의한 기포슬러리의 안정화가 목적이며, 증기양생은 운반, 취급과정, 그리고 오토클레이브양생 시의 압력에 저항할 수 있는 강도 유지를 확보하기 위한 것이다. 안정기는 증기양생 후의 경화체 내부와 외부의 열응력 해소를 위 한 것이다. 오토클레이브양생은 경량기포콘크리트의 강 도발현 및 화학적 결합을 유도하기 위한 것이며 양생조

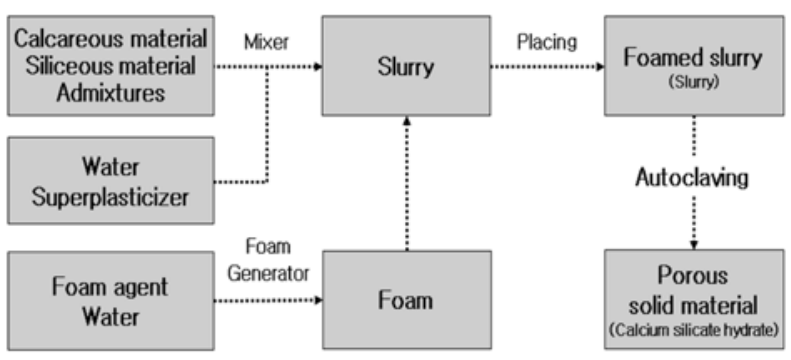

Fig. 1 The making process of porous solid material

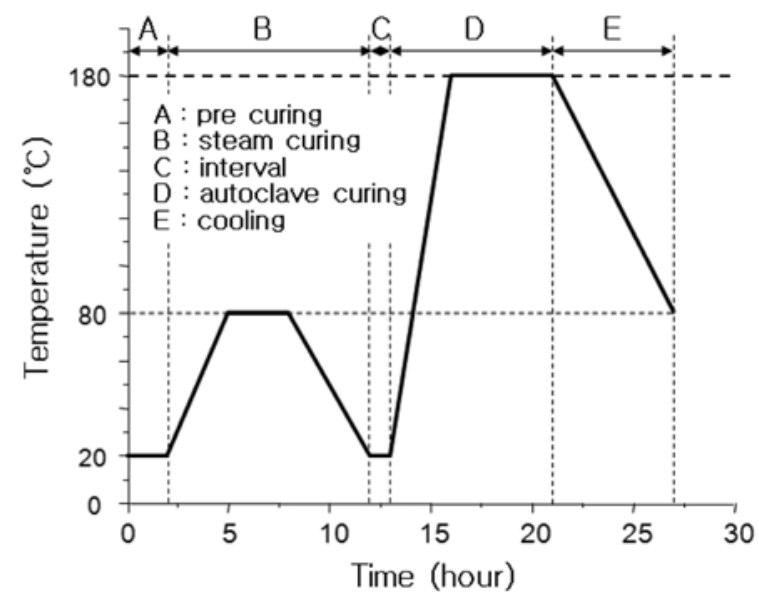

Fig. 2 Curing process
건은 국내 KS F 4914「경량 기포콘크리트 패널」및 참 고문헌 ${ }^{12-14)}$ 을 참조하였다. 서냉기는 오토클레이브 후의 급격한 온도변화에 따른 열응력으로 인한 경화체의 균열 방지를 목적으로 하였다.

\subsection{3 측정}

굳지 않은 상태에서의 기포슬러리의 밀도 및 플로우 시험은 KS F 4039 「현장 타설용 경량기포콘크리트」에 준하여 실시하였으며, 오토클레이브양생 후의 경화체의 밀도 및 압축강도는 KS F 4914 「경량 기포콘크리트 패 널」에 준하여 측정하였다. 오토클레이브양생 후 경화체 의 기공 구조 및 수화물 생성 확인을 위해 광학현미경 $(\mathrm{OM})$, 주사전자현미경(SEM), 엑스선회절분석(XRD)을 하 였다.

\section{5 실험계획법과 통계분석 ${ }^{15)}$}

\subsection{1 이원배치법(two-way factorial design)}

이 실험에서 사용한 실험계획법은 요인배치법 중 이원 배치법이다. 이원배치법은 관심 있는 특성치에 대해서 2 개 인자의 영향을 조사하고자 할 때 사용되는 실험계획 법이다. 따라서 이 연구에서는 오토클레이브양생 경화체 의 제조에 있어 이원배치법에 따라 $\mathrm{C} / \mathrm{S}$ 비와 $\mathrm{W} / \mathrm{B}$ 를 기 술적으로 지정되는 2 개의 중요한 원인으로 취하여 이들 의 조건을 변화시켜 가면서 실험을 실시하였다.

\subsection{2 분산분석(analysis of variance)}

실험에 의하여 얻어지는 데이터의 분석에는 분산분석 이 그 밑바탕을 이루고 있다. 분산분석은 특성치의 산포 를 제곱합으로 나타내고 이 제곱합을 실험과 관련된 요 인마다의 제곱합으로 분해하여 오차에 비해 특히 큰 영 향을 주는 요인이 무엇인가를 찾아내는 분석방법이다.

\section{3. 실험 결과}

\section{1 슬러리 밀도에 대한 통계분석}

Table 3 은 $\mathrm{C} / \mathrm{S}$ 비 및 $\mathrm{W} / \mathrm{B}$ 변화에 따른 슬러리 밀도의 분산분석 결과를 나타낸 것이다. F-검정을 실시한 결과 $\mathrm{F}_{0}$ 값은 $\mathrm{C} / \mathrm{S}$ 비 $5.89, \mathrm{~W} / \mathrm{B} 28.08$ 로 나타났다. 따라서 $\mathrm{C} / \mathrm{S}$

Table 3 The anova table for slurry density

\begin{tabular}{c|c|c|c|c|c|c}
\hline Factor & $\mathrm{S}$ & $\varnothing$ & $\mathrm{V}$ & $\mathrm{F}$ & $\mathrm{F} 0.01$ & $\mathrm{~F} 0.05$ \\
\hline \hline C/S ratio & 0.0065 & 3 & 0.0022 & 5.89 & \multirow{2}{*}{6.99} & \multirow{2}{*}{3.86} \\
\cline { 1 - 5 } W/B & 0.0311 & 3 & 0.0104 & 28.08 & & \\
\hline Error & 0.0033 & 9 & 0.0004 & - & - & - \\
\hline Total & 0.0410 & 15 & - & - & & - \\
\hline
\end{tabular}

$\mathrm{S}:$ the sum of square, $\varnothing$ : the degree of freedom

$\mathrm{V}$ : the mean square

$F$ : the value of $F$ test for the experimental value 
비 유의수준 $\alpha=0.05$ 에서의 기각치 3.86 보다 크게 나타 났고 $\mathrm{W} / \mathrm{B}$ 는 유의수준 $\alpha=0.01$ 에서 기각치 6.99보다 크 게 나타나 $\mathrm{C} / \mathrm{S}$ 비와 $\mathrm{W} / \mathrm{B}$ 가 슬러리 밀도 변화에 모두 영 향을 미침을 알 수 있었으며, $\mathrm{W} / \mathrm{B}$ 가 $\mathrm{C} / \mathrm{S}$ 비 보다 슬러리 밀도에 지배적으로 영향을 끼치는 것으로 분석되었다.

Fig. 3은 $\mathrm{C} / \mathrm{S}$ 비 및 $\mathrm{W} / \mathrm{B}$ 변화에 따른 슬러리 밀도의 변 화를 나타낸 것으로, 대체적으로 $\mathrm{W} / \mathrm{B}$ 가 증가함에 따라 슬러리 밀도는 감소하는 경향을 보였으며, $\mathrm{C} / \mathrm{S}$ 비가 감소 할수록 전반적으로 슬러리 밀도도 감소하는 것으로 나타 났지만 그 차이는 크지 않았다.

미세한 공극으로 구성된 기포, 배합수, 그리고 분체계 재료로 구성된 기포슬러리에서 분체계 재료와 배합수는 슬러리의 무게를 유지한다. 따라서 $\mathrm{W} / \mathrm{B}$ 가 증가하면 상 대적으로 동일 용적에서 배합수보다 중량이 무거운 분체 계 재료는 감소하게 되므로 슬러리 밀도는 감소하는 것 이다. $\mathrm{C} / \mathrm{S}$ 비에 따른 슬러리 밀도의 변화에서는 $\mathrm{C} / \mathrm{S}$ 비가 높아질수록 상대적으로 단위중량이 높은 시멘트의 함량 이 증가하게 된다. 그러므로 $\mathrm{C} / \mathrm{S}$ 비가 높아질수록 슬러리 밀도가 증가하는 것으로 예측할 수 있지만 실험범위 조 건에서는 밀도변화에 크지 않아 슬러리 밀도에서는 상기 전술한 분산분석의 결과와 같이 $\mathrm{W} / \mathrm{B}$ 가 좀 더 슬러리 밀 도에 지배적으로 영향을 끼친 것으로 판단된다.

\section{2 절건밀도에 대한 통계분석}

Table 4는 $\mathrm{C} / \mathrm{S}$ 비 및 $\mathrm{W} / \mathrm{B}$ 변화에 따른 절건밀도의 분 산분석 결과를 나타낸 것이다. $\mathrm{F}$-검정을 실시한 결과, $\mathrm{F}_{0}$ 값은 $\mathrm{C} / \mathrm{S}$ 비 $4.88, \mathrm{~W} / \mathrm{B} 14.23$ 으로 나타나 유의수준 $5 \%$ 에 서는 $\mathrm{C} / \mathrm{S}$ 비가, $1 \%$ 에서는 $\mathrm{W} / \mathrm{B}$ 가 슬러리 밀도와 함께 절 건밀도 변화에도 영향을 미치는 것이 확인되었으며, 절

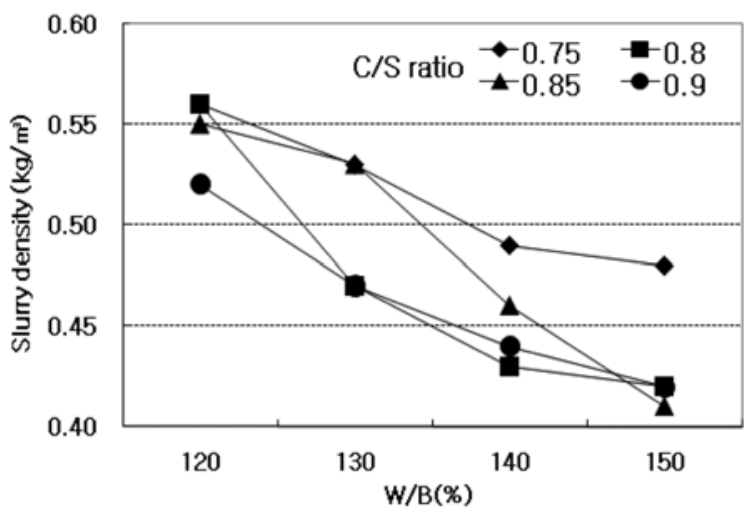

Fig. 3 Slurry density according to the $C / S$ ratio and W/B

Table 4 The anova table for oven dry density

\begin{tabular}{c|c|c|c|c|c|c}
\hline Factor & $\mathrm{S}$ & $\varnothing$ & $\mathrm{V}$ & $\mathrm{F}$ & $\mathrm{F} 0.01$ & $\mathrm{~F} 0.05$ \\
\hline \hline C/S ratio & 0.0073 & 3 & 0.0024 & 4.88 & 6.99 & \multirow{2}{*}{3.86} \\
\hline W/B & 0.0212 & 3 & 0.0071 & 14.23 & 6.99 & \\
\hline Error & 0.0045 & 9 & 0.0005 & - & - & - \\
\hline Total & 0.0330 & 15 & - & - & - & - \\
\hline
\end{tabular}

건밀도에 대해서는 $\mathrm{W} / \mathrm{B}$ 가 $\mathrm{C} / \mathrm{S}$ 비 보다 지배적인 영향요 인으로 분석되었다.

Fig. 4는 W/B 변화에 따른 $\mathrm{C} / \mathrm{S}$ 비별 절건밀도의 변화 를 나타낸 것으로 슬러리 밀도의 변화에서처럼 $\mathrm{W} / \mathrm{B}$ 가 증가할수록 절건밀도는 감소하는 경향을 보였다. $\mathrm{C} / \mathrm{S}$ 비 변화에 따른 경화체의 절건밀도 변화는 $\mathrm{W} / \mathrm{B}$ 의 경우와 같이 유사한 경향을 보였으며, $\mathrm{C} / \mathrm{S}$ 비 실험조건 간의 밀 도 변화의 차이는 크지 않았다. $\mathrm{W} / \mathrm{B}$ 변화에서는 $\mathrm{W} / \mathrm{B}$ 가 증가할수록 경화체의 밀도는 점차적으로 감소하는 것으 로 나타났는데, 이러한 밀도변화의 원인으로는 슬러리 밀 도의 변화와 같이 단위수량의 증가로 인한 경화체 메트 릭스의 구성요소인 분체계 재료의 용적감소 때문으로 판 단된다.

\section{3 압축강도에 대한 통계분석}

Table 5 는 $\mathrm{C} / \mathrm{S}$ 비 및 $\mathrm{W} / \mathrm{B}$ 변화에 따른 경화체의 절건 밀도의 분산분석 결과를 나타낸 것이다. $\mathrm{F}$-검정을 실시 한 결과, $\mathrm{F}_{0}$ 값은 $\mathrm{C} / \mathrm{S}$ 비는 $1.95, \mathrm{~W} / \mathrm{B}$ 는 0.12 로 유의수준 $1 \%$ 및 $5 \%$ 의 기각치 보다 낮게 나타나 압축강도 변화에 영향을 끼치지 않는 것으로 나타났다.

Fig. 5는 $\mathrm{C} / \mathrm{S}$ 비 및 $\mathrm{W} / \mathrm{B}$ 변화에 따른 경화체의 압축강 도 변화를 나타낸 것으로 $\mathrm{C} / \mathrm{S}$ 비 0.85 경화체의 압축강도 가 다른 배합조건의 경화체보다 다소 높은 압축강도를 보이는 것으로 나타났다. 오토클레이브양생 경화체의 수 화물 중 강도특성을 좌우하는 토버모라이트의 결정 생성 은 규산칼슘 뿐만 아니라 증기양생된 콘크리트 제품에서 도 강도와 중요한 관계를 가진다. ${ }^{16)}$ 토버모라이트의 결 정 생성은 원료의 종류, 수열합성조건, 반응시간 등 모

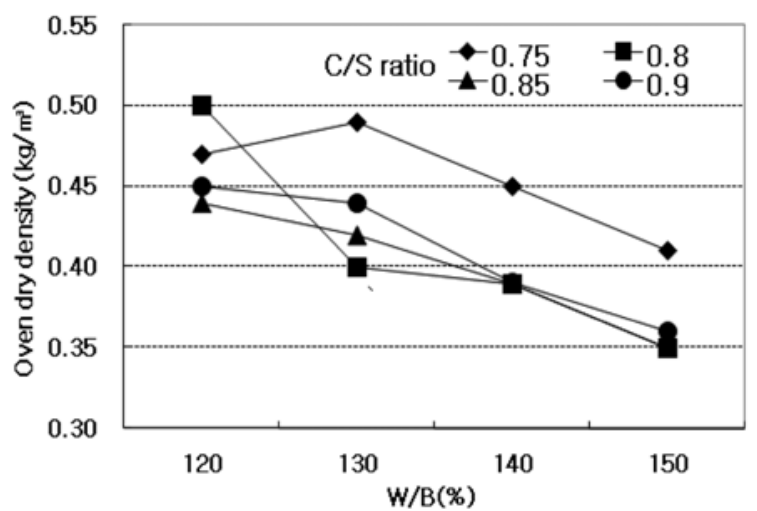

Fig. 4 Oven dry density according to the C/S ratio and W/B

Table 5 The anova table for compressive strength

\begin{tabular}{c|c|c|c|c|c|c}
\hline Factor & $\mathrm{S}$ & $\varnothing$ & $\mathrm{V}$ & $\mathrm{F}$ & $\mathrm{F} 0.01$ & $\mathrm{~F} 0.05$ \\
\hline \hline C/S ratio & 0.1919 & 3 & 0.0640 & 1.95 & \multirow{2}{*}{6.93} & \multirow{2}{*}{3.86} \\
\cline { 1 - 5 } W/B & 0.0119 & 3 & 0.0040 & 0.12 & & \\
\hline Error & 0.2956 & 9 & 0.0328 & - & - & - \\
\hline Total & 0.4994 & 15 & - & - & - & - \\
\hline
\end{tabular}




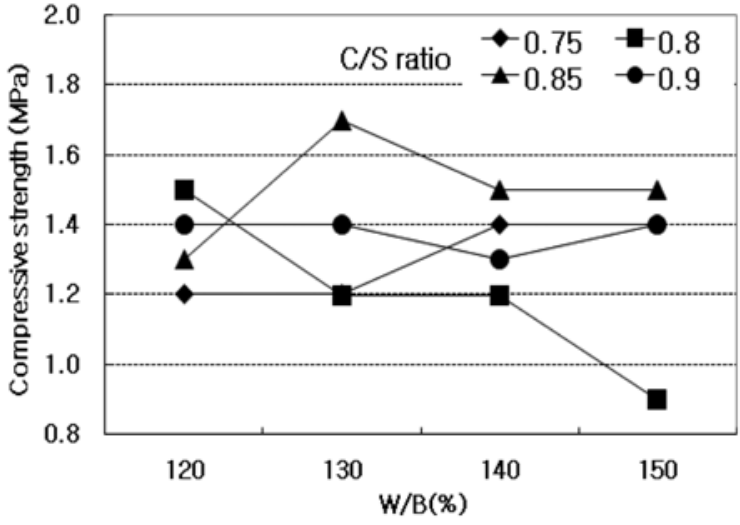

Fig. 5 Compressive strength according to the C/S ratio and W/B

든 조건에 영향을 받는 것으로 알려져 있다. ${ }^{17)}$ 또한, 토 버모라이트 결정 전이 현상은 사용재료 및 양생조건이 동일한 경우에서 $\mathrm{C} / \mathrm{S}$ 비가 높아질수록 빠르게 되는 것을 기존 연구를 통해 알 수 있었다. ${ }^{16)}$ 이러한 기존 연구를 근거로 해서 볼 때 토버모라이트의 결정 전이 현상이 가 장 빠른 $\mathrm{C} / \mathrm{S}$ 비 0.9 가 강도도 높게 발현될 수 있을 것으 로 예상했지만 실제적인 결과치는 다르게 나와 $\mathrm{C} / \mathrm{S}$ 비 이 외에도 전술한 바와 같이 여러 다른 요인의 변화에 따 라 강도변화는 나타날 수 있는 것으로 판단되었다.

따라서 이러한 것들을 바탕으로 이 연구의 결과에서 $\mathrm{C} / \mathrm{S}$ 비 0.85 의 압축강도가 가장 높았지만 매우 안정적으 로 높은 강도를 발현하는 것이 아니므로 $\mathrm{C} / \mathrm{S}$ 비 0.85 가 압축강도 발현에 가장 좋다고 할 수는 없을 것으로 판 단되며 추후 세부적인 $\mathrm{C} / \mathrm{S}$ 비 변화에 따른 강도변화분석 이 필요할 것으로 사료된다. $\mathrm{W} / \mathrm{B}$ 변화에서도 일부 $\mathrm{C} / \mathrm{S}$ 비에서 $\mathrm{W} / \mathrm{B}$ 증가에 따라 강도가 감소하는 경향을 알 수
있었지만 명확하게 강도변화에 영향을 끼친다는 것을 판 명하기는 어려웠다. 그러므로 이 부분에 대해서도 앞서 기술한 $\mathrm{C} / \mathrm{S}$ 비의 변화와 함께 추가적인 분석이 필요할 것 으로 판단된다.

\section{4 미세구조 및 X선회절분석}

Fig. 6은 오토클레이브양생 후의 경화체 중에서 $\mathrm{C} / \mathrm{S}$ 비 0.85 시편을 주사전자현미경(SEM)으로 미세구조를 관찰 한 것이다. 수화물의 형태는 얇은 판상형(plate-like)의 수 화물이 서로 겹쳐진 형상을 나타내고 있다. 수열합성으로 생성되는 토버모라이트는 판상형(plate-like), ${ }^{18)}$ 편상형(lathlike), ${ }^{19)}$ 섬유형(fibrous)의 다양한 결정구조를 나타내며, ${ }^{20)}$ 토버모라이트는 생성이 잘 될수록 서로 겹쳐 있는 판상형 (lath-like)이 높은 강도를 나타내는 것으로 보고되고 있다. ${ }^{21)}$

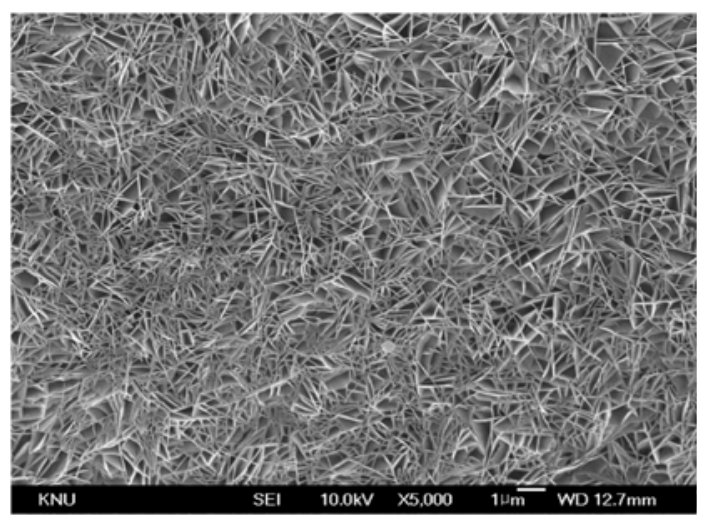

Fig. 6 Hydrates generated by hydro-thermal synthetic reaction $(\times 5,000)$

Table 6 Mix design and results of test

\begin{tabular}{|c|c|c|c|c|c|c|c|c|c|c|c|}
\hline \multirow{2}{*}{$\mathrm{C} / \mathrm{S}$ ratio } & \multicolumn{2}{|c|}{ W/B (\%) } & \multicolumn{6}{|c|}{$(\mathrm{Wt}, \%)$} & \multicolumn{2}{|c|}{ Density $\left(\mathrm{kg} / \mathrm{m}^{3}\right)$} & \multirow{2}{*}{$\begin{array}{l}\text { Compressive } \\
\text { strength (MPa) }\end{array}$} \\
\hline & $\mathrm{MW}^{*}$ & $\mathrm{FW}^{* *}$ & SP & OPC & $\mathrm{AC}$ & $\mathrm{CH}$ & $\mathrm{A}$ & AES & Slurry & Dry & \\
\hline \multirow{4}{*}{0.75} & 50 & 70 & \multirow{4}{*}{43.87} & \multirow{4}{*}{45.15} & \multirow{4}{*}{6.77} & \multirow{4}{*}{2.43} & \multirow{4}{*}{4.06} & \multirow{4}{*}{0.3} & 0.56 & 0.47 & 1.2 \\
\hline & 50 & 80 & & & & & & & 0.53 & 0.49 & 1.2 \\
\hline & 50 & 90 & & & & & & & 0.49 & 0.45 & 1.4 \\
\hline & 50 & 100 & & & & & & & 0.48 & 0.41 & 1.4 \\
\hline \multirow{4}{*}{0.8} & 50 & 70 & \multirow{4}{*}{39.72} & \multirow{4}{*}{46.50} & \multirow{4}{*}{6.89} & \multirow{4}{*}{2.58} & \multirow{4}{*}{4.31} & \multirow{4}{*}{0.3} & 0.56 & 0.50 & 1.5 \\
\hline & 50 & 80 & & & & & & & 0.47 & 0.40 & 1.2 \\
\hline & 50 & 90 & & & & & & & 0.43 & 0.39 & 1.2 \\
\hline & 50 & 100 & & & & & & & 0.42 & 0.35 & 0.9 \\
\hline \multirow{4}{*}{0.85} & 50 & 70 & \multirow{4}{*}{37.83} & \multirow{4}{*}{48.02} & \multirow{4}{*}{7.20} & \multirow{4}{*}{2.59} & \multirow{4}{*}{4.32} & \multirow{4}{*}{0.3} & 0.55 & 0.44 & 1.3 \\
\hline & 50 & 80 & & & & & & & 0.53 & 0.42 & 1.7 \\
\hline & 50 & 90 & & & & & & & 0.46 & 0.39 & 1.5 \\
\hline & 50 & 100 & & & & & & & 0.41 & 0.35 & 1.5 \\
\hline \multirow{4}{*}{0.9} & 50 & 70 & \multirow{4}{*}{36.09} & \multirow{4}{*}{49.30} & \multirow{4}{*}{7.30} & \multirow{4}{*}{2.74} & \multirow{4}{*}{4.56} & \multirow{4}{*}{0.3} & 0.52 & 0.45 & 1.4 \\
\hline & 50 & 80 & & & & & & & 0.47 & 0.44 & 1.4 \\
\hline & 50 & 90 & & & & & & & 0.44 & 0.39 & 1.3 \\
\hline & 50 & 100 & & & & & & & 0.42 & 0.36 & 1.4 \\
\hline
\end{tabular}

$\mathrm{MW}^{*}$ : mixing water, $\mathrm{FW}^{* *}$ : foaming water 


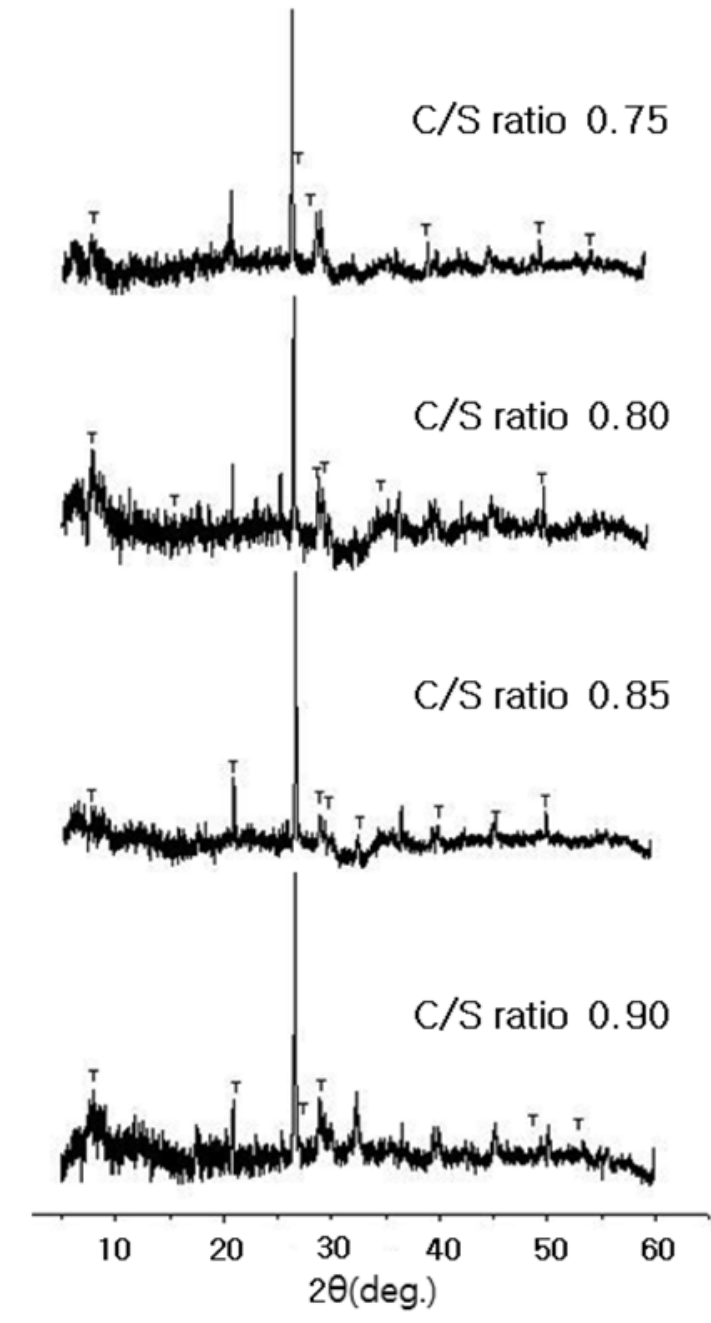

Fig. 7 X-ray diffraction according to the variation of $\mathrm{C} / \mathrm{S}$ ratio

Fig. 7은 $\mathrm{C} / \mathrm{S}$ 비에 따른 경화체의 엑스선회절분석(XRD) 을 통하여 구성광물 및 수화물을 비교 분석한 것으로 오 토클레이브양생 경화체 모두에서 $\mathrm{C} / \mathrm{S}$ 비와는 상관없이 토 버모라이트가 잘 형성되었음을 알 수 있었다.

\section{5 현미경 관찰}

Figs. 8 10은 이 연구에서 제조한 경화체와 오토클레 이브를 사용하여 제조되는 기존의 제품을 광학 현미경을 이용하여 기공의 형상을 관찰하였다. 이 연구에서 제조 한 경화체는 일본 $\mathrm{D}$ 사 흡음용 경량기포콘크리트와 유사 하게 모두 큰 기공 내부에 작은 기공이 다량 존재하고 대부분이 연결 기공으로 되어 있음을 알 수 있었다. ALC 의 경우에는 제조과정에서 발생되는 수소가스의 방출로 형성되는 닫힌 공극이 공극의 대부분을 차지하는 것으로 나타났다. Fig. 8은 시험체 중 $\mathrm{C} / \mathrm{S}$ 비 0.85 경화체와 일본 $\mathrm{D}$ 사 제품 및 국내 $\mathrm{S}$ 사 제품을 비교한 것이다.

이와 같이, 시험체의 현미경 관찰을 통해 연구개발한 시험체와 기존의 흡음형 다공성 경화체의 기공 형상이 유사함을 알 수 있었으며 후속적인 연구에서는 기공 및 공극특성에 관한 추가적인 연구를 진행할 계획이다.

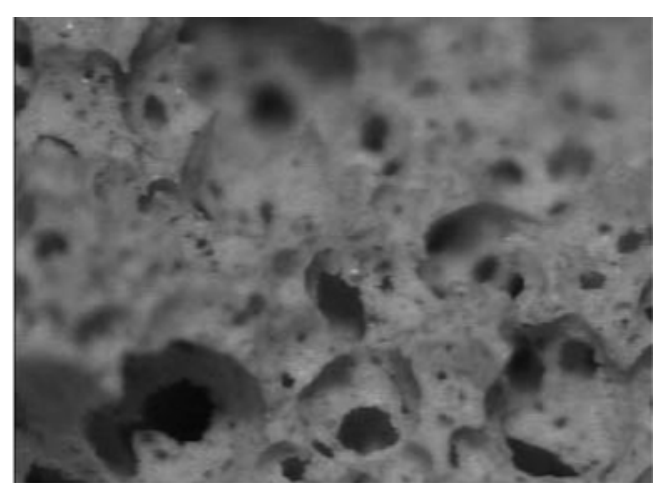

Fig. 8 Microscope observation of C/S ratio 0.85

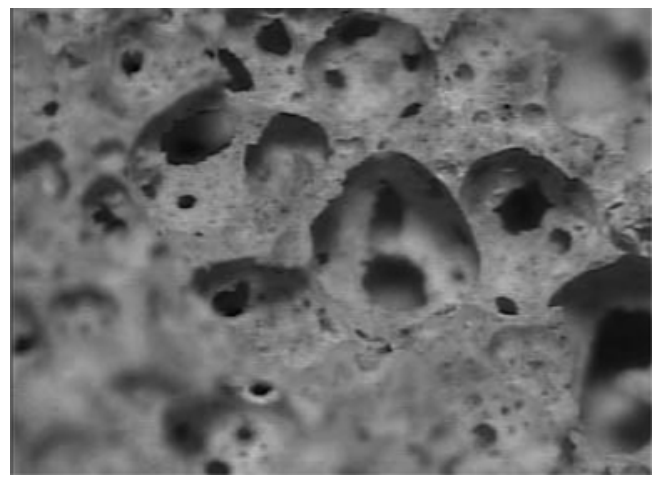

Fig. 9 Microscope observation of sound absorbing material of D company (Japan)

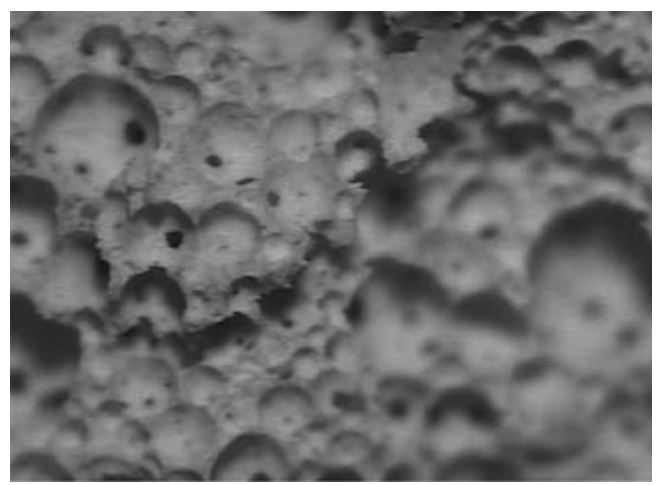

Fig. 10 Microscope observation of ALC

\section{4. 결 론}

1) 슬러리 밀도에서는 $\mathrm{C} / \mathrm{S}$ 비가 감소할수록, $\mathrm{W} / \mathrm{B}$ 가 증 가할수록 밀도는 감소하는 것으로 나타났다. $\mathrm{C} / \mathrm{S}$ 비 및 $\mathrm{W} / \mathrm{B}$ 는 슬러리 밀도 변화에 유의한 영향을 끼치 는 것으로 나타났으며, $\mathrm{W} / \mathrm{B}$ 가 슬러리 밀도 변화에 지배적이었다. 절건밀도에서도 슬러리 밀도와 유사 한 경향을 나타냈으며, $\mathrm{W} / \mathrm{B}$ 가 절건밀도 변화에 더 영향을 끼치는 것으로 나타났다.

2) 압축강도의 변화에서는 시멘트량이 많을수록 강도 가 증가하는 일반 상온양생 경화체와는 달리, 오토 
클레이브양생 경화체에서는 $\mathrm{C} / \mathrm{S}$ 비 0.85 에서 강도가 가장 높게 나타났지만, 강도발현이 다른 $\mathrm{C} / \mathrm{S}$ 비와 크 지 않아 $\mathrm{W} / \mathrm{B}$ 변화와 함께 세부적인 연구가 필요할 것으로 판단되었다.

3) 주사전자현미경과 $X$ 선회절분석으로 경화체의 미세 구조를 관찰한 결과, 경화체 모두에서 오토클레이 브양생 수화물인 토버모라이트가 고르게 생성된 것 으로 나타났다.

4) 광학 현미경 관찰 결과, 이 연구에서 제조한 경화 체는 일본 $\mathrm{D}$ 사의 무기질 흡음형 기포콘크리트와 유 사하게 연속공극을 구성하는 것으로 나타났다.

\section{감사의 글}

이 연구는 전력산업연구개발의 연구비 지원에 의해 공 주대학교 자원재활용신소재 지역혁신센터(RIC/NMR)가 수행한 연구 결과의 일부로 관련기관에 감사드립니다.

\section{참고문헌}

1. 남재현, “경량기포콘크리트, ALC 제조방법 및 특성을 중 심으로," 한국강구조학회논문집, 3권, 4호, 1991, pp. 111 115.

2. Mitsuda, T., "Autoclaved Calcium Silicate Products," Ceramics, Vol. 23, No. 8, 1998, pp. 748 752.

3. Mitsuda, T., "Hydrothermal Reaction and Industry of Calcium Silicates," Ceramics, Vol. 15, No. 3, 1990, pp. 184 196.

4. Sudo, N. and Akiba, T., "Introduction to Cement Chemistry," Japan Cement Industry Association, 1991, pp. 15 20.

5. Tada, M., "Autoclaved Lightweight Concrete," Gypsum \& Lime, Vol. 222, 1971, pp. 26 30.

6. Hara, T. and Inoue, N., "Shirasu-lime System of the Alc," Gypsum \& Lime, Vol. 110, 1998, pp. 26 30.

7. 양관섭, 건축물의 음환경설계와 음향재료, 건설기술정보, 제 172호, 1999, pp. 3 11.

8. Allard, J. F., Herzog, P., Lafarge, D., and Tamura, M.,
"Recent Topics Concerning the Acoustics of Fibrous and Porous Materials," Applied Acoustics, Vol. 39, Issue 1 2, 1993, pp. 3 21.

9. Taylor, H. F. W., The Chemistry of Cements, Vol. 1, Academy Press, London and New York, 1964, pp. 181 186.

10. Mitsuda, T., Sasaki, K., and Ishida., H., "Phase Evolution during Autoclaving Process of Aerated Concrete," Journal of the American Ceramic Society, Vol. 75, No. 7, 1992, pp. 1858 1863.

11. 이주민, “재생자원을 이용한 흡음재의 흡음특성에 관한 연구," 선문대학교 대학원, 석사학위논문, $2001,12 \mathrm{pp}$.

12. 한국콘크리트학회, 최신콘크리트공학, 한국콘크리트학회, 2007, 697 pp.

13. Mindess, S., Young, J. F., and Darwin, D., Concrete, Second Edition, Pearson Education, Inc, 2003, pp. 7 11.

14. RILEM Technical Committees, Autoclaved Aerated Concrete Properties, Testing and Design, Taylor \& Francis, London and New York, 1993, pp. 7 11.

15. 박성현, 현대실험계획법, 민영사, 2003, pp. 7 12.

16. 홍성수, "Tobermorite의 수열합성과 ALC에 관한 연구," 충남대학교 대학원, 박사학위논문, 1992, pp. 21, 47 52.

17. Gimblett, F. G. R. and Qazi, M. U. Z., "Factors Influencing the Porosity and Surface Characteristics of Anomalous Synthetic Tobermorites," Journal of Colloid and Interface Science, Vol. 123, No. 1, 1988, pp. 148 160.

18. American Concrete Institute., ACI Concrete Terminology, ACI, 2008, 75 pp.

19. Connan, H, Ray, A. S., and Thomas, P., "Autoclaved Lime-Colloidal Silica Slurries and Formation of AlTobermorite," Journal of Australian Ceramics Society, Vol. 43, No. 2, 2007, pp. 150 153.

20. Stanley, B. and Caleb, M., "Hydrothermal Products Formed from Montmorillonite Clay System," Clays and Clay Minerals, Vol. 9, No. 1, 1960, pp. 276 294.

21. Liu, B., Ray, A. S., and Thomas, P., "Strength Development in Autoclaved Aluminosilicate Rich Industrial Waste Cement Systems Containing Reactive Magnesia," Journal of Australian Ceramics Society, Vol. 43, No. 1, 2007, pp. 82 87.

요 약 이 연구는 수열합성반응을 통해 규사분을 사용한 무기질 다공성 규산칼슘 재료의 특성에 관한 것으로, 다양 한 제조과정에 의해 발생하는 규산질 부산물을 사용한 소음 저감용 다공성 경화체 개발을 위한 기초적 자료로 사용하 고자 하였다. 오토클레이브 양생 시편의 제조를 위해 다양한 칼슘질 재료를 사용하였고 규산질 재료는 규사분을 사용 하였다. 이 연구에서, $\mathrm{W} / \mathrm{B}$ 와 $\mathrm{C} / \mathrm{S}$ 비에 따라 밀도와 강도 특성, 공극의 형태를 위한 현미경, 오토클레이브양생 후의 수화 물 검사를 위해 주사전자현미경과 엑스선회절분석을 각각 수행하였다. 측정 결과로 굳지 않은 상태에서 $\mathrm{W} / \mathrm{B}$ 가 증가할 수록 슬러리 밀도는 점점 감소하고 이러한 경향은 굳은 상태에서도 유사하게 나타났다. 압축강도는 $\mathrm{C} / \mathrm{S}$ 비 0.85 시편이 가장 높게 나타났다. 토버모라이트는 $\mathrm{C} / \mathrm{S}$ 비와는 상관없이 모든 시편에서 생성되었다. 공극구조를 확인하기 위해, 기존 에 사용되고 있는 다공질 규산칼슘 제품(ALC, 무기질 흡음재)을 비교했다. 관찰 결과, 기존의 무기질 흡음형 다공성 경 화체 기공과 유사한 형상을 보였다. 따라서 이러한 결과를 바탕으로 소음저감형 다공성 경화체의 개발 가능성을 확인 할 수 있었다.

핵심용어 : 오토클레이브, 수열합성반응, $\mathrm{C} / \mathrm{S}$ 비, 토버모라이트, 기공 